\title{
Evaluation of Fungicides and Bioformulations against Ustilaginoidea virens causing Rice False Smut Disease
}

\author{
H. K. Deva Nath ${ }^{1 *}$ and B. C. Das ${ }^{2}$ \\ ${ }^{1}$ Department of Plant Pathology, Assam Agricultural University, Jorhat, (Assam), India \\ ${ }^{2}$ Regional Agricultural Research Station, Assam Agricultural University, Titabar, (Assam), \\ India \\ *Corresponding author
}

\section{A B S T R A C T}

\section{Keywords}

Bioformulations,

False smut,

Fungicides, Rice,

Ustilaginoidea

virens

Article Info

Accepted:

22 October 2020

Available Online:

10 November 2020
In the present study three fungicides viz., copper oxychloride, copper hydroxide and propiconazole and five bioformulations viz., Biotime, TNAU-Pf1, G-Derma, G-Pseudo and Taegro Eco were evaluated in vitro on the rice false smut pathogen Ustilaginoidea virens during 2017. Among the different fungicides and bioformulations tested, copper oxychloride, copper hydroxide and propiconazole showed complete inhibition (100\%) of the growth of $U$. virens followed by 95.95 per cent by Taegro Eco (a Bacillus based bioformulation) after 14 days of inoculation. G-Pseudo, a Pseudomonas based bioformulation recorded the minimum inhibition $(61.10 \%)$ over control.

\section{Introduction}

Rice false smut (RFS) disease caused by Ustilaginoidea virens (Cooke) Takahashi has become the most devastating grain disease in almost all the rice growing areas throughout the world. The disease was also known as 'Laksmi disease' of rice because the occurrence of the disease was considered as a symbol of bumper harvest. Historically, the disease has been categorized as a minor disease due to its sporadic occurrence in certain regions and causing insignificant yield loss regularly. However, the disease has emerged in severe form due to high input cultivation, heavy application of nitrogenous fertilizer, large scale planting of hybrid varieties and climate change (Lu et al., 2009; Ladhalakshmi et al., 2012; Guo et al., 2012; Zhang et al., 2014). The disease affects the grains and the symptoms produced are visible only after flowering. Usually only few grains are affected in a panicle but the number may rise up to 100 in case of severe disease incidence (Ladhalakshmi et al., 2012). The disease results in both reductions in quality 
and quantity of rice. It is an important devastating disease and causes yield losses of 1.01 to 10.91 per cent (Atia, 2004). In India, depending on the disease intensity and varieties grown the yield losses caused by false smut in different states have been estimated to vary between 0.2 to 49 per cent (Doden and Singh, 1996). Besides, the disease results in generating mycotoxins that impose significant health hazards (Nakamura et al., 1994; Koiso et al., 1994), thereby raising great concerns for food and feed safety. As adopted in other crop diseases, chemical control could be an option for managing rice false smut. Due to the limitations of chemical control, the biological control of RFS is the future direction of development. The present study was undertaken to evaluate the relative efficacy of fungicides and bioformulations in inhibiting the growth of $U$. virens under in vitro condition.

\section{Materials and Methods}

The experiment was conducted at Department of Plant Pathology, Assam Agricultural University, Jorhat, Assam, India during 2017. Three fungicides (viz., copper oxychloride, copper hydroxide and propiconazole) and five bioformulations (viz., Biotime, TNAU-Pf1, G-Derma, G-Pseudo and Taegro Eco) (Table 1) were tested to find out their relative efficacy in inhibiting the growth of $U$. virens under in vitro conditions by employing Poisoned Food Technique (Schmitz, 1930).

Required quantity of each fungicide and bioformulation was added to potato sucrose agar (PSA) medium prior to solidification and thoroughly mixed them by shaking prior to pouring in sterilized Petri plates. The medium was allowed to solidify. Fungal culture were cut $(5 \mathrm{~mm})$ with the help of sterilized cork borer from 20 days old culture and then placed at the center of Petri plates with sterilized inoculation needle. The fungal bit was reversed so that the pathogen could come in direct contact with the medium. Plates inoculated with only pathogen served as control (i.e. medium without any fungicide or bioformulation). All the Petri plates were then incubated at $27 \pm 1^{\circ} \mathrm{C}$ for 14 days. The plates were arranged in a completely randomized block (CRD) design and each treatment were replicated thrice.

Radial growth of the test fungus for the each treatment was taken at 7 and 14 days after incubation. The per cent inhibition over control was calculated for each treatment by Vincent's (1947) formula.

$\mathrm{I}=[(\mathrm{C}-\mathrm{T}) / \mathrm{C}] \times 100$

Where,

$\mathrm{I}=$ Per cent inhibition,

$\mathrm{C}=$ Radial growth of fungus in control, and

$\mathrm{T}=$ Radial growth of fungus in treatment.

\section{Results and Discussion}

The mycelial growth and per cent inhibition of the growth of tested pathogen with different fungicides and bioformulations at 7 and 14 days after incubation were presented in Table 2 and Plate 1. All the fungicides and bioformulations tested significantly inhibited the mycelial growth of $U$. virens ( 78.5 to 100 $\%)$ over control. The maximum mycelial inhibition percentage of growth of fungus $(100 \%)$ was recorded with copper oxychloride (Blue copper 50), copper hydroxide (Kocide 2000) and propiconazole (Tilt) followed by Taegro Eco (95.95\%) and TNAU-Pf (85.86\%) after 14 days after inoculation. The minimum inhibition percentage of growth $(61.10 \%)$ was recorded in G-Pseudo. Several reports stated that propiconazole (Tripathi et al., 2014; Bhargava et al., 2018; Ladhalakshmi et al., 2019) and copper oxychloride (Ahonsi and Adeoti, 2003; Tokpah et al., 2017) were 
highly effective in inhibiting mycelial growth of $U$. virens.

The performance of the bio-formulation treatment might be due to the action of the antagonistic fungus that involves mycoparasitism, antibiosis, competition for nutrients and space. The antagonists also secrete extracellular enzymes like glucanase, chitinase etc. to degrade the mycelia of pathogen and to reduce the colonization of pathogen (Köhl et al., 2019).

Table.1 Details of fungicides and bioformulations evaluated under in vitro condition

\begin{tabular}{|c|l|c|}
\hline SI. No. & \multicolumn{1}{|c|}{ Fungicides/ bioformulations } & $\begin{array}{c}\text { Doses } \\
\text { (g or ml/lit.) }\end{array}$ \\
\hline $\mathbf{1}$ & Copper oxychloride (Blue Copper 50) & $4.0 \mathrm{~g}$ \\
\hline $\mathbf{2}$ & Copper hydroxide (Kocide 2000) & $2.5 \mathrm{~g}$ \\
\hline $\mathbf{3}$ & Propiconazole 25\% EC (Tilt) & $1.0 \mathrm{ml}$ \\
\hline $\mathbf{4}$ & $\begin{array}{l}\text { Biotime }\left(1 \times 10^{7} \mathrm{cfu} / \mathrm{g}\right) \text { (Pseudomonas flourescens, } \\
\text { Trichoderma harzianum and Metarhizium anisopliae) }\end{array}$ & $20.0 \mathrm{~g}$ \\
\hline $\mathbf{5}$ & TNAU-Pf $1\left(1 \times 10^{9} \mathrm{cfu} / \mathrm{g}\right)$ (Pseudomonas flourescens) & $2.0 \mathrm{~g}$ \\
\hline $\mathbf{6}$ & G- Derma $1 \times 10^{9} \mathrm{cfu} / \mathrm{ml}($ Trichoderma flavofusum) & $2.0 \mathrm{ml}$ \\
\hline $\mathbf{7}$ & G-Pseudo $\left(1 \times 10^{9} \mathrm{cfu} / \mathrm{ml}\right)$ (Pseudomonas biviar) & $2.0 \mathrm{ml}$ \\
\hline $\mathbf{8}$ & Taegro Eco $\left(1 \times 10^{10} \mathrm{cfu} / \mathrm{g}\right)$ (Bacillus subtilis) & $2.0 \mathrm{~g}$ \\
\hline
\end{tabular}

Table.2 Effect of different fungicides and bioformulations on mycelial growth of $U$. virens

\begin{tabular}{|l|c|c|c|c|}
\hline \multirow{2}{*}{ Treatments } & \multicolumn{2}{|c|}{ 7 DAI } & \multicolumn{2}{c|}{ 14 DAI } \\
\cline { 2 - 5 } & $\begin{array}{c}\text { Mycelial } \\
\text { growth }(\mathbf{m m})\end{array}$ & $\begin{array}{c}\text { Per cent } \\
\text { inhibition }\end{array}$ & $\begin{array}{c}\text { Mycelial } \\
\text { growth }(\mathbf{m m})\end{array}$ & $\begin{array}{c}\text { Per cent } \\
\text { inhibition }\end{array}$ \\
\hline Blue copper & 0.00 & $100.00(89.13)^{\mathrm{a}}$ & 0.00 & $100.00(89.38)^{\mathrm{a}}$ \\
\hline Copper hydroxide & 0.00 & $100.00(89.13)^{\mathrm{a}}$ & 0.00 & $100.00(89.38)^{\mathrm{a}}$ \\
\hline Propeconazole & 0.00 & $100.00(89.13)^{\mathrm{a}}$ & 0.00 & $100.00(89.38)^{\mathrm{a}}$ \\
\hline Biotime & 3.67 & $66.21(54.49)^{\mathrm{d}}$ & 3.78 & $82.82(65.51)^{\mathrm{c}}$ \\
\hline TNAU-Pf & 2.44 & $77.53(61.76)^{\mathrm{c}}$ & 3.11 & $85.86(68.00)^{\mathrm{c}}$ \\
\hline G-Derma & 5.00 & $53.96(47.29)^{\mathrm{e}}$ & 6.67 & $69.68(56.73)^{\mathrm{d}}$ \\
\hline G-Pseudo & 5.11 & $52.95(46.70)^{\mathrm{e}}$ & 8.56 & $61.10(51.54)^{\mathrm{d}}$ \\
\hline Taegro Eco & 0.89 & $91.80(73.42)^{\mathrm{b}}$ & 0.89 & $95.95(78.43)^{\mathrm{b}}$ \\
\hline Control & 10.86 & $0.00(0.86)^{\mathrm{f}}$ & 22.00 & $0.00(0.62)^{\mathrm{e}}$ \\
\hline SEd $\mathbf{( \pm )}$ & & 3.322 & & 2.610 \\
\hline CD $(\mathbf{0 . 0 5 )}$ & & 6.979 & & 5.485 \\
\hline
\end{tabular}

DAI: days after inoculation

Data are mean of four replications. Means in the same column followed by different letter are significantly different at $\mathrm{P}=0.05$ by DMRT technique

Figures in the parentheses are arc sine transformed value 

Plate.1 Efficacy of different fungicides and bioformulations on mycelial growth
of $U$. virens 14 days after inoculation

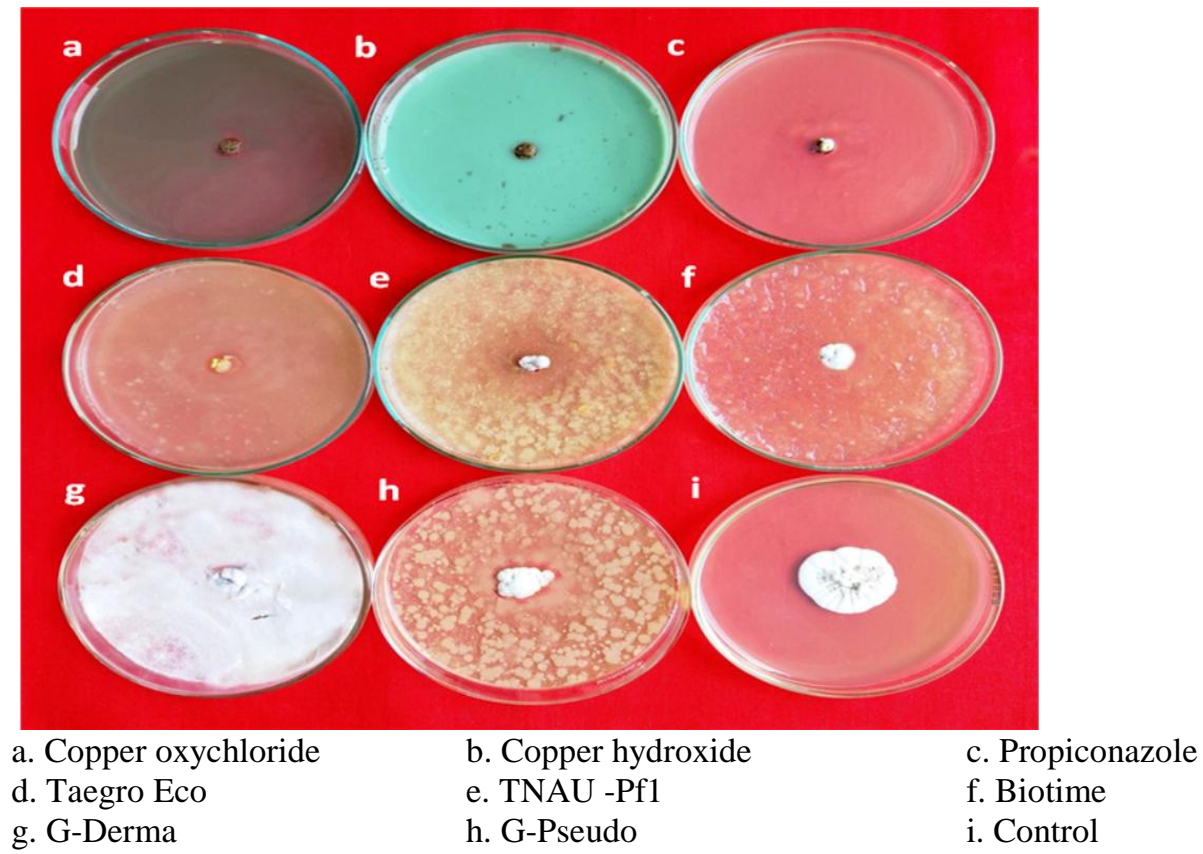

Chitarra et al., (2003) reported that a number of antifungal compounds, including polypeptides that interact with the fungal membrane, are produced by Bacillus species. Bacillus can secrete chitinases and chitinbinding proteins; together these proteins control fungi by binding to cell wall chitin and disrupting the cell polarity, leading to fungal growth inhibition. Yin et al., (2011) found that among 1800 bacterial isolates isolated from the soil, SF-62 and SF-3-38 of Bacillus subtilis grew quickly, and had a strong inhibition effect on the growth of $U$. virens, the inhibition rates reached $97.2 \%$ and $85.9 \%$, respectively. Kannahi et al., (2016) studied the antagonistic potential of four isolates of Trichoderma spp. viz., T. viride, $T$. virens, $T$. harzianum and $T$. reesei obtained from rice rhizosphere under in vitro condition and reported that all the isolates of Trichoderma showed antagonistic activity against $U$. virens. Gopalakrishnan and Valluvaparidasan (2006) reported that different isolates of $T$ viride, $P$, fluorescens and $B$. subtilis showed inhibitory effect on
Sarocladium oryzae ranging from 10.90 to 82.18 per cent.

\section{Acknowledgement}

The authors are grateful to the Department of Plant Pathology, Assam Agricultural University, Jorhat, Assam for providing experimental facilities for this study.

\section{References}

Ahonsi, M.O. and Adeoti, A.A. 2003. Evaluation of fungicides for the control of false smut of rice caused by Ustilaginoidea virens (Cooke) Tak. Moor Journal of Agricultural Research, 4 (1):118-122.

Atia, M.M.M. 2004. Rice false smut (Ustilaginoidea virens) in Egypt. Journal of Plant Diseases and Protection, 111 (1): 71-82.

Bhargava, P., Kumar, A., Kumar, S. and Azad, C.S. 2018. Impact of fungicides and nanoparticles on Ustilaginoidea 
virens causing false smut disease of rice. Journal of Pharmacognosy and Phytochemistry, 7(1):1541- 1544.

Chitarra, G. S., Breeuwer, P., Nout, M. J. R., Van Aelst, A. C., Rombouts, F. M., \& Abee, T. 2003. An antifungal compound produced by Bacillus subtilis YM 10-20 inhibits germination of Penicillium roqueforti conidiospores. Journal of Applied Microbiology, 94(2): 159-166.

Dodan, D.S. and Singh, R. (1996). False smut of rice: Present status. Agricultural Reviews-Agricultural Research Communications Centre India, 17(4): 227-240.

Gopalakrishnan, C., and Valluvaparidasan, V. 2006. Seed-borne biocontrol agents for the management of rice sheath rot caused by Sarocladium oryzae (Sawada) W. Gams \& D. Hawksw. Journal of Biological Control, 20(2): 197-204.

Guo, X., Li, Y., Fan, J., Li, L., Huang, F. and Wang, W. 2012. Progress in the study of false smut disease in rice. Journal of Agricultural Science and Technology, 2: 1211-1217.

Kannahi, M., Dhivya, S. and Senthilkumar, R. 2016. Biological control on rice false smut disease using Trichoderma species. International Journal of Pure and Applied Bioscience, 4(2): 311-316.

Köhl, J., Kolnaar, R., and Ravensberg, W. J. 2019. Mode of action of microbial biological control agents against plant diseases: relevance beyond efficacy. Frontiers in Plant Science, 10: 845.

Koiso, Y., Li, Y., Iwasaki, S., Hanaoka, K., Kobayashi, T., Sonoda, R., Fujita,Y., Yaegashi, H. and Sato, Z. 1994. Ustiloxins, antimitotic cyclic peptides from false smut balls on rice panicles caused by Ustilaginoidea virens. Journal of Antibiotics. 47(7): 765-773.

Ladhalakshmi, D., Laha, G.S., Singh, R., Karthikeyan, A., Mangrauthia, S.K.,
Sundaram, R.M., Thukkaiyannan, P. and Viraktamath, C. 2012. Isolation and characterization of Ustilaginoidea virens and survey of false smut disease of rice in India. Phytoparasitica, 40: 171-176.

Ladhalakshmi, D., Madamsetty, S.P., Vellaichamy, P., Donempudi, K., Banda, S., Singh, R., Prasad, V., Lore, J.S., Jain, J., Mariappan, S. and Laha, G.S. 2019. Geographic distribution of false smut disease of rice in India and efficacy of selected fungicides for its management. International Journal of Pest Management, 65(2): 177-185.

Lu, D.H., Yang, X.Q., Mao, J.H., Ye, H.L., Wang, P., Chen, Y.P., He, Z.Q. and Chen, F. 2009. Characterising the pathogenicity diversity of Ustilaginoidea virens in hybrid rice in China. Journal of Plant Pathology, 91(2): 443-451.

Nakamura, K., Izumiyama, N., Ohtsubo, K., Koiso, Y. and Iwasaki, S. 1994. "Lupinosis"- like lesions in mice caused by ustiloxin produced by Ustilaginoidea virens: A morphological study. Natural Toxins, 2(1): 22-28.

Schmitz, H. 1930. Poisoned food technique. Industrial and Engineering ChemistryAnalytical Edition / Indust. and Engin. Chem. Analyti. Ed. 2(4): 361-363.

Tokpah, D.D., Charles K.C., Tokpah, E.S. and Kolleh, D. 2017. Rice false smut and its management in major rice growing areas in Ashanti region of Ghana. African Journal of Agricultural Research, 12(43): 3129-3136

Tripathi, S., Mishra, P. and Sinha, A.P. 2014. In-vitro evaluation of fungicides against Ustilaginoidea virens (Cke.) Takahashi, the incitant of false smut of rice. International Journal of Basic and Applied Agricultural Research, 12(3): 379-381.

Vincent, J.M. 1947. Distortion of fungal hyphae in the presence of certain 
inhibitors. Nature, 159:850.

Yin, X., Chen, Z., Liu, Y., Liu, Y., Wang, X., Luo, C., ... Nie, Y. 2011. Screening and evaluation of antagonistic bacteria against rice false smut. Jiangsu Journal of Agricultural Science, 27(5): 983-989.
Zhou, B., Sun, X., Li, S.,. ..... and Sun, W. 2014. Specific adaptation of Ustilaginoidea virens in occupying host florets revealed by comparative and functional genomics. Nature Communications, 5: 3849 .

\section{How to cite this article:}

Deva Nath, H. K. and Das, B. C. 2020. Evaluation of Fungicides and Bioformulations against Ustilaginoidea virens causing Rice False Smut Disease. Int.J.Curr.Microbiol.App.Sci. 9(11): 3165-3170. doi: https://doi.org/10.20546/ijcmas.2020.911.381 